\title{
Adjusting Labour Demand: Multinational vs. National Firms A Cross-European Analysis
}

\author{
Giorgio Barba Navaretti \\ (University of Milan and Centro Studi Luca d'Agliano) \\ Daniele Checchi \\ (wTw, University of Milan) \\ Alessandro Turrini \\ (UNCTAD, University of Bergamo, CEPR and Centro Studi Luca d'Agliano)
}

August 2002

Paper prepared for the invited session on 'Multinationals and Labour Markets', annual meeting of the European Economic Association, Venice August 22-24, 2002. The authors are extremely thankful to Alessandra Tucci for skilful and very patient research assistance. This paper is part of the outcome of the 'Labour Market Effects of Foreign Direct Investments' project, funded by the European Commission under the Socio-Economic Research Programme. 


\title{
Adjusting Labour Demand: Multinational vs. National Firms A Cross-European Analysis
}

\begin{abstract}
This paper provides a cross-country perspective to the firm-level analysis of the relation between foreign ownership and labour demand. We estimate labour demand equations in eleven European countries using dynamic panel data techniques on samples that permit to distinguish the ownership status of firms. We find that the employment adjustment is significantly faster in MNEs' affiliates, irrespective of the country investigated. As for the wage elasticity of labour demand, MNEs show smaller elasticities compared with national firms, and very little variation across countries. Crosscountry correlations show that the relative value of wage elasticities in MNEs on that in NEs is positively related to country-level indexes of labour market regulation (employment protection, union presence,...). We interpret the results as follows. MNEs tend to have a more rigid demand for total labour (possibly due to a different skill composition). However, being MNEs relatively "footloose", this difference tends to vanish as the rigidity of employment regulations rises.
\end{abstract}

Keywords: Multinational firms, labour demand elasticity, employment adjustment costs.

JEL Classification: F23, J23. 


\section{Introduction}

This paper addresses one particular aspect of the globalisation-labour market nexus, namely the implications of inward FDIs activity on the characteristics of labour demand in host countries. FDI flows directed to developed economies, mainly in the form of mergers and acquisitions, have been growing at an accelerated pace throughout the past decade (see, e.g., UNCTAD (1999), Lipsey (2000), Shatz and Venables (2001)). Especially in the case of European countries, a substantial share of productive activities currently falls under foreign control. ${ }^{1}$ Policy makers and economic actors participate to this tendency with mixed feelings. On the one hand, inward FDIs are generally perceived to benefit domestic employment by increasing productivity in the owned plants and generating positive spillovers to local firms. On the other hand, because of the "footloose" nature of multinational firms, the concern is sometimes raised that employment downsizing in response to negative shocks would occur more easily in foreign-owned plants, so that inward FDIs would also be associated with higher job insecurity and reduced unions' power.

There are reasons to expect that multinational enterprises (henceforth MNEs) may adjust employment in their subsidiaries more easily and less costly than domestic firms (henceforth NEs). First of all, MNEs have the possibility of relocating employment across subsidiaries, and this helps to reduce costs related to firing and hiring personnel. Second, multinational firms may be able to bargain from a privileged position with (national or local) governments and unions, thus obtaining sometimes exceptions on hiring and firing practices. ${ }^{2}$ Moreover, being MNEs less committed towards the countries hosting their subsidiaries, they may be in a better position to resist the pressures coming by public authorities concerned with local employment conditions. The fact that a given establishment is owned by an MNE may have implications not only for the speed of employment adjustment but also for the magnitude of the adjustment in response to given shocks. In particular, this may matter in terms of wage elasticity. On the one hand, the overall labour demand in MNEs subsidiaries is likely to be more rigid, because characterized by a higher intensity of skilled labour, estimated to be less elastic to wages (see, e.g., Hamermesh (1993)). ${ }^{3}$ On the other hand, keeping equal the skill composition of labour

\footnotetext{
1 The inward FDI stock (as a percentage of GDP) was 11.1 in Western Europe in 1990 and 22.4 in 1999, while the same figures were 9.2 and 17.3 for the world average and 8.4 and 14.5 for developed countries on aggregate (UNCTAD (2001)). 2There is evidence, for instance, that MNEs have managed in a number of countries to bargain wages at a more decentralized level compared with domestic firms (Katz (1993), Ehremberg (1994)). Moreover, in some countries and regions (e. g., export processing zones) less stringent hiring and firing rules have been granted to MNEs with the purpose of attracting FDI. For theoretical models of wage bargaining between unions and multinationals see Mezzetti and Dinopoulos (1991) and Zhao (1998).

${ }^{3}$ See also Markusen (2002) for a survey of stylised facts on MNEs and for theory and evidence on the relation between the multinational status and the skill composition of employment.
} 
demand, the wage elasticity in MNEs' subsidiaries is expected to be higher than that in purely national firms since MNEs have the option of relocating activities or shifting employment across countries in response to wage changes. This asymmetric position of MNEs as employers has a number of consequences for the countries hosting FDIs. First, the degree of labour turnover in the host country may increase as inward FDIs become more abundant. Second, there may be effects related with changes in the demand elasticity for particular skill categories. In particular, if demand for unskilled labour is more elastic in MNEs' subsidiaries, union mark-ups may fall and a greater share of the wedge between labour costs and wages (payroll taxes,...) will be effectively paid by workers (see, e.g., Rodrik (1997) on this points).

While the relation between foreign ownership, productivity and wages has been extensively investigated empirically, there is little work analysing the impact of inward FDI on labour demand adjustment and on the elasticity of labour demand. ${ }^{4}$ The aim of this paper is that of contributing to fill this gap by providing a cross-country perspective to the firm-level analysis of the relation between foreign ownership and labour demand. The paper focuses on the relation between foreign ownership and the characteristics of labour demand in given firms, while the effects on the pattern of firms' shutdowns/openings are not investigated. In particular, we address the following questions: Is the adjustment of employment systematically faster in MNEs' subsidiaries? Is there any significant difference in labour demand elasticities between national firms and MNEs' affiliates? How does the different employment behaviour of MNEs relate with country-level labour market regulations?

Our data set is an unbalanced panel covering more than ten thousand companies located in eleven European countries observed in the period 1993-2000. The source of our data is the "Amadeus" database collected by Bureau Van Dijk. We estimate firm-level, constant output labour demand equations separately in each country by means of Arellano-Bond (1991) GMM estimators for dynamic panel data. The ownership status of firms (foreign or national) is assumed to potentially affect the speed of technical progress, wage and output labour demand elasticities, and employment adjustment costs.

Our estimates are largely supportive of the view that employment adjustment in foreign owned firms is faster than in purely domestic companies, after controlling for sector and size effects. Employment changes are in fact significantly less persistent for MNEs' subsidiaries, and this is a feature that characterises all countries analysed. As for the wage elasticity of labour demand, there is clear

\footnotetext{
${ }^{4}$ One of the few exceptions is Fabbri, Haskel and Slaughter (2002), who compare the evolution of labour demand elasticities for MNEs and national firms in the UK.
} 
evidence that the long-run demand for labour is more rigid in MNEs' affiliates. We interpret this result in the light of the different skill composition of labour demand in multinational firms.

Finally, the cross-country pattern of wage elasticities in national establishments and MNEs' subsidiaries is put in relation with country-level labour market regulation variables (mainly from OECD source). We find that while the long-run wage elasticity in foreign-owned plants has very little variation across countries, country-level characteristics seem to matter for the elasticity in domestic plants. In particular, the wage elasticity in national plants appears to be less elastic in countries with more regulated labour markets. We interpret this evidence by referring to the wider set of instruments available to MNEs to bypass "de-jure" or "de-facto" labour market regulations. This makes MNEs relatively less affected by country-level measures of labour market rigidity.

The remainder of the paper is organised as follows. In the next section we survey the related empirical literature. In section 3 we present our empirical estimates, while in section 4 we correlate our estimates with alternative proxies for adjustment costs. Section 5 concludes.

\section{Related literature}

A number of papers have analysed the relation of inward FDI with wage levels (among others, Lipsey (1994), Doms and Jensen (1996), and and Feliciano and Lipsey (1999)). A common finding is that, on average, MNEs' subsidiaries in the US pay higher wages when compared with domestically owned establishments. Lipsey (1994) shows that the wage difference paid by MNEs becomes insignificant after controlling for firm size, while Feliciano and Lipsey (1999), limiting the analysis to manufacturing sectors, find that a wage premium in foreign-owned manufacturing establishments remains significant also after controlling for establishment, industry and state characteristics. ${ }^{5}$ The usual explanation for this wage premium paid in MNEs' subsidiary is a productivity advantage in plants falling under foreign control (for empirical evidence see, e.g., Davies and Lyons (1991), Doms and Jensen (1998), Griffith (1999), Girma, Greenaway, and Wakelin (2002), and Benfratello and Sembenelli (2002)). ${ }^{6}$ Other work has instead concentrated the focus on the effects of inward FDI on wage inequality. Feenstra and Hanson (1997) and Aitken, Harrison and Lipsey (1996) show that inward FDI in Mexico have contributed to raise the wage gap between skilled and unskilled workers significantly. Conversely,

\footnotetext{
5 Similar results are obtained in Globerman, Ries and Vertinsky (1994) for Canada, in Girma, Greenaway and Wakelin (2001) for the UK and in Aitken, Harrison and Lipsey (1996), who compare the experience of the US, Mexico and Venezuela.

${ }^{6}$ An alternative explanation maybe higher firm-level profitability for MNEs coupled with international profit sharing (Budd, Konings and Slaughter (2002)).
} 
Blonigen and Slaughter (1999) do not find an effect on skill upgrading associated with inward FDIs in the US.

The effects of FDI on demand elasticities and employment volatility have been analysed from different corners and following alternative methodologies. Some studies investigate the degree of substitutability of employment in MNEs' plants located in different countries. Brainard and Riker (1997a), using firm-level data on US multinationals find that the degree of substitution between employment in parent companies in the US and in foreign affiliates is low. However, the same authors show that substitution between employment in subsidiaries in alternative low wage locations is quite strong (Brainard and Riker, 1997b). Bruno and Falzoni (1999), use sector-level data for the US to estimate dynamic factor demand equations in MNEs. They show that the substitution effects for employment across subsidiaries are limited to the short run, while in the long run complementarity effects tend to prevail. Brakonier and Ekholm (2000) look at firm-level data on Swedish multinationals and find that there is some evidence of substitution between employment in parent companies and employment in subsidiaries located in high-income countries, but not in those in low-income countries. $^{7}$ Finally, Konings and Murphy (2001) use firm-level data on multinational firms of all EU countries. The authors find a substitution relationship between employment in parent companies and in subsidiaries, which is significant especially in the case of affiliates located within the EU.

Other papers analyse directly the impact of "globalisation" measures on labour demand elasticities. Most of this work limits the analysis to the effects of international trade. Results show in general little relation between trade integration and labour demand elasticities (Slaughter (2001), Bruno, Falzoni, and Helg (2001), Fanlzylber and Maloney (2000), Krishna, Mitra, and Chinoy (2001)). ${ }^{8}$ To our knowledge, Fabbri, Haskel and Slaughter (2002) is the only paper providing a comparison of the elasticity of labour demand in national and multinational firms. They estimate plant-level demand equations for production and non-production labour in the UK. Their results show that over time the wage elasticity of demand for production labour has been rising faster in plants belonging to MNEs.

The footloose nature of MNEs has been investigated with a more direct approach in Gorg and Strobl (2002), who look at inward FDI in Ireland. In this paper, using a Cox proportional hazard model, it is analysed whether, controlling for other plant and industry-specific characteristics, there is a significant difference between the survival rate of domestic and foreign-owned plants, and whether employment changes in MNEs are more or less persistent than those occurring in domestic plants.

\footnotetext{
${ }^{7}$ A substitution relationship between parent and affiliate employment for Swedish MNEs is also found in Hatzius (1998). In this paper, however, there is no distinction between the locations of the subsidiaries.

${ }^{8}$ However, in Faini et. al. (1999) it is found a positive rank correlation across Italian manufacturing sectors between the values of labour demand elasticities and the share of employment in foreign subsidiaries.
} 
Results show that multinationals are more likely to shut down operations, that job creation in foreignowned plants tend to be more persistent, while there is no significant difference between persistence of job destruction in foreign or domestic plants. A similar result concerning the likelihood of plant shutdowns is found in Fabbri, Haskel and Slaughter (2002) in their work on the UK. Plants belonging to MNEs are more likely to be shut down than domestic plants, conditional on a set of plant and industry characteristics.

\section{The empirical analysis}

\subsection{Description of the data}

The aim of this section is to compare labour demands in MNEs' affiliates and in national firms (henceforth NEs) in a sample that allows to analyse separately eleven European countries (Belgium, Denmark, Finland, France, Germany, Italy, The Netherlands, Spain, Sweden and the United Kingdom). ${ }^{9}$ The source of the data is the Amadeus database, a commercial database collected by Bureau Van Dijk that reports balance sheet and other information for about 5 million firms in 31 countries between 1993 and 2000. This is the only data set for which it is possible to carry out crosscountry analyses comparing NEs and MNEs. ${ }^{10}$ We restrict our analysis to manufacturing firms in the eleven sample countries that reported ownership status. From these we exclude firms with less than 50 employees and/or with less than three observations for the employment variable. ${ }^{11}$ The final total number of firms used is 14,900 . Their distribution by country is reported in Table 1 .

\footnotetext{
9. These are the countries for which a sufficiently high number of firms reporting ownership status was available.

10 According to Amadeus dataset, a foreign firm is such when its 'ultimate owner' is non-resident in the country analysed. An ultimate owner can be a company, a public authority, a state, a mutual fund, a pension fund, a nominee, a trust or a trustee that owns at least $50 \%$ of the company. This information on the ownership status is not as accurate as we would have liked. First, it is time invariant, as the database does not report this information by year. As a consequence, for all the period, we classify as MNEs the firms which are foreign-owned in 2000. Second, information on the outward activities of firms is often missing, so that it is not possible to distinguish between national firms with or without foreign subsidiaries: Third, there is no information on firms' closure, as the data set only reports information on firms which were active in 2000.

${ }^{11}$ Data for firms with less than 50 employees are quite often not reliable, when not missing altogether.
} 
Table 1. The data set: summary statistics (reference year: 1998)

\begin{tabular}{|c|c|c|c|c|c|c|c|c|c|c|c|}
\hline & Belgium & Denmark & Spain & Finland & France & Germany & Italy & $\begin{array}{l}\text { Nether- } \\
\text { lands }\end{array}$ & Norway & Sweden & $\begin{array}{l}\text { United } \\
\text { Kingdom }\end{array}$ \\
\hline N. of firms ${ }^{a}$ & 586 & 233 & 1039 & 167 & 3273 & 323 & 1783 & 234 & 1079 & 1859 & 4324 \\
\hline Of which MNEs (\%) & 65.02 & 48.07 & 40.52 & 31.14 & 38.41 & 46.13 & 27.26 & 73.93 & 14.64 & 13.56 & 47.29 \\
\hline Total Employment & 194.360 & 54.675 & 250.757 & 36.242 & 910.055 & 476.341 & 295.098 & 292.107 & 53.141 & 300.446 & 1.514 .182 \\
\hline Of which in MNEs (\%) & 85.10 & 41.62 & 55.67 & 24.15 & 33.19 & 44.38 & 49.05 & 58.97 & 34.50 & 27.32 & 45.01 \\
\hline $\begin{array}{l}\text { Employees in the sample } \\
\text { as \% of total national } \\
\text { manufacturing } \\
\text { employment }\end{array}$ & 29.67 & 12.17 & 9.08 & 8.20 & 24.03 & 5.87 & 5.68 & 27.22 & - & 40.33 & 33.78 \\
\hline $\begin{array}{l}\text { For comparison: } \\
\text { manufacturing } \\
\text { employment in foreign } \\
\text { MNEs as reported by } \\
\text { OECD statistics }{ }^{c}\end{array}$ & n.a. & n.a. & n.a. & 13.80 & 27.80 & 6.00 & 8.8 & 21.90 & 17.40 & 21.80 & 17.80 \\
\hline
\end{tabular}

Notes:

a The firms in the sample are in manufacturing and larger than 50 employees

b Source OECD STAN database, OECD , 2001

c OECD (2001), Measuring Globalisation, Volume I: Manufacturing Sector, OECD Paris, 2001

The coverage of the final data set of national manufacturing activities varies by country, from $40.33 \%$ in Sweden to $5.68 \%$ in Italy. Also, MNEs are over-represented compared to their share in national manufacturing employment, mainly because of the exclusion of firms smaller than 50 employees. However, average output per employee and average cost of employment per employee for NEs and MNEs in the sample (Table A1) are in line with those at the population level, according to OECD data. Consistently with most of the available evidence, MNEs in the sample report higher output per employee and employment costs per employee than NEs. This gap, which is robust when we control for size and sector distribution (unreported), is possibly related to higher skill intensity in MNEs. Regrettably, in our sample we cannot directly measure this effect, as we have no information on the skill composition of employment.

\subsection{The econometric model and results}

We are interested in measuring both the speed and the extent of labour demand adjustment across firms. We derive from a Cobb Douglas production function a constant-output dynamic labour demand function for a generic cost-minimising firm under the assumption of partial adjustment of the type $\frac{L_{i t}}{L_{i t-1}}=\left(\frac{L_{i t}^{*}}{L_{i t-1}}\right)^{\lambda}$, where $0 \leq \lambda \leq 1$, while $L_{i t}$ and $L_{i t}^{*}$ are, respectively, effective and desired employment in firm $i$ at time $t$. In logarithmic form, the firm-level conditional labour demand is derived as follows, 


$$
l_{i t}=\gamma_{0}+\gamma_{1} l_{i t-1}+\gamma_{2} y_{i t}+\gamma_{3} r_{t}-\gamma_{4} w_{t}+\gamma_{5} T+\varepsilon_{i t}
$$

where $l_{i t}$ is $(\log )$ employment in firm $i$ at time $t, y_{i t}$ is real output, $r_{t}$ the (real) rental cost of capital, $w_{t}$ real wages and $T$ a time trend to control for (Hicks-neutral) technical progress. ${ }^{12}$ How variables are measured and constructed is described in Appendix 2. The speed of adjustment is negatively related to the persistency in time of labour demand $\left(\gamma_{1}\right)$, and equal to $\left(1-\gamma_{1}\right)$. The extent of the adjustment is measured by the elasticity with respect to output $\left(\gamma_{2}\right)$ and factor prices $\left(\gamma_{3}\right.$ and $\left.\gamma_{4}\right)$. The effect of technical progress is captured by the coefficient $\gamma_{5}$. To account for unobservable components at the firm level we estimate equation (1) in first differences. ${ }^{13}$

To test whether labour demand parameters are significantly different between MNEs and NEs, we introduce a dummy variable mne, which is 1 when the firm is owned by a foreign MNE and 0 otherwise. This dummy is interacted with the explanatory variables so as to derive different sets of coefficients for the two types of firms: ${ }^{14}$ After re-expressing equation (1) in first differences we obtain:

$$
\begin{aligned}
\Delta l_{i t}= & \gamma_{1} \Delta l_{i t-1}+\gamma_{2} \Delta y_{i t}+\gamma_{3} \Delta r_{i t}-\gamma_{4} \Delta w_{i t}+\gamma_{5}+\gamma_{6} m n e_{i} \Delta l_{i t-1} \\
& +\gamma_{7} m n e_{i} \Delta y_{i t}+\gamma_{8} m n e_{i} \Delta r_{i t}-\gamma_{9} m n e_{i} \Delta w_{i t}+\gamma_{10} m n e_{i}+\mu_{i t}
\end{aligned}
$$

Note that the MNE status of firms (the mne dummy) may be capturing also the effect of other factors (mainly industry or size). For this reason, we have introduced size and sector controls by interacting $j$, $j=1,2, \ldots, J$, size classes and $k, k=1,2, \ldots, K$, sector dummies with the trend term as follows: ${ }^{15}$

$$
\begin{aligned}
\Delta l_{i t}= & \gamma_{1} \Delta l_{i t-1}+\gamma_{2} \Delta y_{i t}+\gamma_{3} \Delta r_{i t}-\gamma_{4} \Delta w_{i t}+\gamma_{5}+\sum_{j=i}^{J} \gamma_{5 j}^{D} \operatorname{Dim}_{j}+\sum_{k=1}^{K} \gamma_{5 k}^{S} \operatorname{Sect}_{k} \\
& +\gamma_{6} \text { mne }_{i} \Delta l_{i t-1}+\gamma_{7} m n e_{i} \Delta y_{i t}+\gamma_{8} m n e_{i} \Delta r_{i t}-\gamma_{9} m n e_{i} \Delta w_{i t}+\gamma_{10} m n e_{i}+v_{i t}
\end{aligned}
$$

\footnotetext{
${ }^{12}$ Note that in equation (1) labour and capital earnings are expressed in real terms, by using industry-level producer price indexes as deflators (see Appendix 2). We do not include in the equation the (real) prices for other inputs (intermediates, materials, energy...) assuming they are closely correlated with industry-level producer price indexes.

${ }^{13} \mathrm{It}$ is known that that using differenced variables aggravates measurement errors. The use of long time differences (5 years or more) attenuates the problem (Griliches and Hausman (1986)). In our case, however, this strategy would have implied a very severe reduction in the number of observations.

${ }^{14} \mathrm{~A}$ similar methodology can also be found in Bruno, Falzoni and Helg (2002), a paper examining the effects of trade integration and MNEs on sectoral labour demands.

15 As for size, a fivefold partition is used: up to 100, 100-250, 250-500, 500-1000 and above 1000 employees. As for sectors, the following partition is used, based on Pavitt's classification: two supplier dominated sectors, two scale-intensive sectors, one specialised supplier sector and one science-based sector.

Controls have also been carried out by interacting all variables with size and sectoral dummies. Results are in general robust, particularly to the inclusion of size dummies. However, when all potential interactions are introduced, the number of coefficients increases remarkably and the interpretation becomes harder. For this reason, these results are not reported.
} 
OLS estimates are biased and inconsistent if the lagged variable is correlated with the error term, as it is frequent in dynamic panels with a short time dimension. Equation (3) is therefore estimated by using the GMM estimators proposed by Arellano and Bond (1991).

Table 2 reports the econometric results separately for the eleven sample countries. Coefficients $\gamma_{2}, \gamma_{3}$ and $\gamma_{4}$ are short-run output and factor price elasticities of labour demand for NEs. They all have the expected sign, they are generally significant, and their values fall in ranges generally thought as admissible (Hamermesh (1993)). Coefficients $\gamma_{7}, \gamma_{8}$ and $\gamma_{9}$ capture the difference in these elasticities between MNEs and NEs. These interacted terms are mostly not significant. This implies that short-run output and factor price elasticities are not significantly different between MNEs and NEs. The exceptions are Denmark, Spain and France where wage elasticities of MNEs (given by $\gamma_{4}+\gamma_{9}$ ) are smaller (in absolute values). The coefficient $\gamma_{1}$ measures the persistence of labour demand for national firms, which as expected is for all countries smaller than one. The coefficient $\gamma_{6}$ measures the difference of persistence between national and multinational firms, and is always negative and significant. The fact that the sum $\left(\gamma_{1}+\gamma_{6}\right)$ is very close to 0 for all countries means that MNEs adjust their labour demands almost fully within a year, and do that significantly faster than national firms.

Summing up, we find that short-run wage and output elasticities are in the expected ranges and that they do not differ significantly between MNEs and NEs. In contrast, we find that MNEs adjust within one year to shocks affecting labour demand, much faster than national firms. Given the difference in the speed of adjustment of labour demands between NEs and MNEs it is important to compare the two groups of firms in terms of their long term elasticities. These are discussed in the next section. 
Table 2 : Econometric results Dependent variable $l_{i t}$ - sample period 1994-2000

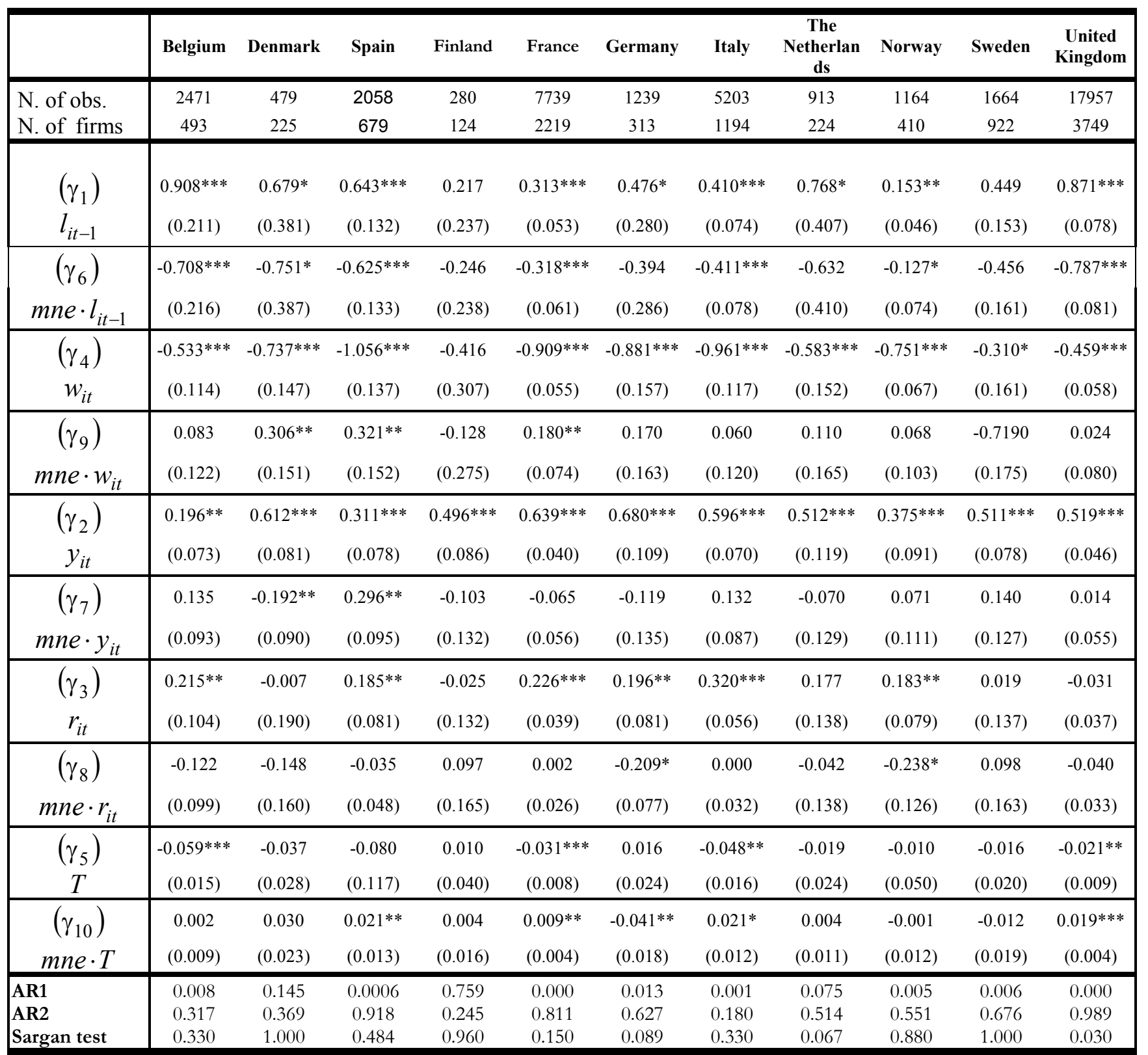

Robust standard errors in parentheses - Time dummies and controls by size and sector included - GMM results are one-step estimates with heteroskedasticity-consistent standard errors and test statistics - AR1 and AR2 are tests for first order and second order serial correlation, P-values are reported - Sargan is a test of the overidentifying restrictions for the GMM estimators, the P-values reported refer to the two-step GMM estimators. *** statistically significant at 99 percent confidence level; ** statistically significant at 95 percent confidence level; * statistically significant at 90 percent confidence level 


\section{Adjustment costs, wage elasticities and national labour markets}

In Table 3 we summarise our main findings: MNEs exhibit a speed of adjustment that in many cases is undistinguishable from unity, whereas NEs have adjustment lags that are longer on average and with a much higher cross-country variation. Despite rather similar short-run (impact) wage elasticities, longrun values are considerably higher for NEs in almost all countries. Moreover, while long-run elasticities do not appear to vary much across countries in the case of MNEs (all values are in the range -0.45, 0.9), the elasticities of national firms seem much more affected by country-level characteristics. A similar picture emerges when comparing short and long-run output elasticities. ${ }^{16}$

Table 3 - Short-run and long-run wage and output elasticities

\begin{tabular}{|c|c|c|c|c|c|c|c|c|c|c|}
\hline \multirow[b]{3}{*}{ Beloium } & \multicolumn{2}{|c|}{$\begin{array}{l}\text { Speed of } \\
\text { adjustment }\end{array}$} & \multicolumn{2}{|c|}{$\begin{array}{l}\text { short-run } \\
\text { wage elast. }\end{array}$} & \multicolumn{2}{|c|}{$\begin{array}{l}\text { long-run } \\
\text { wage elast. }\end{array}$} & \multicolumn{2}{|c|}{$\begin{array}{l}\text { Short-run } \\
\text { Output elast. }\end{array}$} & \multicolumn{2}{|c|}{$\begin{array}{l}\text { Long-run } \\
\text { Output elast. }\end{array}$} \\
\hline & $\mathrm{NE}$ & MNE & $\mathrm{NE}$ & MNE & $\mathrm{NE}$ & MNE & $\mathrm{NE}$ & MNE & $\mathrm{NE}$ & MNE \\
\hline & 0.09 & 0.80 & -0.53 & -0.45 & -5.77 & -0.56 & 0.20 & 0.33 & 2.13 & 0.41 \\
\hline Denmark & 0.32 & 1.07 & -0.74 & -0.43 & -2.30 & -0.40 & 0.61 & 0.42 & 1.91 & 0.39 \\
\hline Spain & 0.36 & 0.98 & -1.06 & -0.73 & -2.96 & -0.75 & 0.31 & 0.61 & 0.87 & 0.62 \\
\hline Finland & 0.78 & 1.03 & -0.42 & -0.54 & -0.53 & -0.53 & 0.50 & 0.39 & 0.63 & 0.38 \\
\hline France & 0.69 & 1.00 & -0.91 & -0.73 & -1.32 & -0.73 & 0.64 & 0.57 & 0.93 & 0.57 \\
\hline Germany & 0.52 & 0.92 & -0.88 & -0.71 & -1.68 & -0.77 & 0.68 & 0.56 & 1.30 & 0.61 \\
\hline Italy & 0.59 & 1.00 & -0.96 & -0.90 & -1.63 & -0.90 & 0.60 & 0.73 & 1.01 & 0.73 \\
\hline The Netherlands & 0.23 & 0.86 & -0.58 & -0.47 & -2.51 & -0.55 & 0.51 & 0.44 & 2.21 & 0.51 \\
\hline Norway & 0.85 & 0.97 & -0.75 & -0.68 & -0.89 & -0.70 & 0.37 & 0.45 & 0.44 & 0.46 \\
\hline Sweden & 0.55 & 1.01 & -0.31 & -0.50 & -0.56 & -0.50 & 0.51 & 0.65 & 0.93 & 0.65 \\
\hline United Kingdom & 0.13 & 0.92 & -0.46 & -0.43 & -3.55 & -0.47 & 0.52 & 0.53 & 4.01 & 0.58 \\
\hline $\begin{array}{l}\text { Definition } \\
\text { (see equation (3)) }\end{array}$ & $1-\gamma_{1}$ & $1-\gamma_{1}-\gamma_{6}$ & $\gamma_{4}$ & $\gamma_{4}+\gamma_{9}$ & $\frac{\gamma_{4}}{1-\gamma_{1}}$ & $\frac{\gamma_{4}+\gamma_{9}}{1-\gamma_{1}-\gamma_{6}}$ & $\gamma_{2}$ & $\gamma_{2}+\gamma_{7}$ & $\frac{\gamma_{2}}{1-\gamma_{1}}$ & $\frac{\gamma_{2}+\gamma_{7}}{1-\gamma_{1}-\gamma_{6}}$ \\
\hline
\end{tabular}

The finding that MNEs have lower long-run wage elasticities can be rationalised in terms of the higher skill intensity of their work force. Skilled personnel generally cover important roles in a firm, and with time it cumulates specific human capital that is essential to the activities of the firm and that cannot be disposed of easily. Regrettably, we cannot control for the skill mix in our sample, but the finding that average labour cost per employee is invariably higher in MNEs, even after controlling for size and industry is consistent with the presumption that MNEs are relatively skill intensive.

Lower adjustment costs are the dominant factor explaining MNEs` faster speed in adjusting employment at the desired levels. Adjustment costs, in turn, are related to hiring and firing costs, but procedural obstacles could also be relevant. Hiring costs are related to labour availability -- in terms of both skill levels and willingness to work -- while firing costs are related to the ease of dispose of unwanted employment (the degree of "labour market rigidity"). Procedural costs can also be due to

\footnotetext{
${ }^{16}$ By imposing a unitary speed of adjustment to all enterprises (assumptions that work against NEs, because according to estimated coefficients in Table 2 in the short run they are off their labour demand curves), we have also used repeated cross section estimation as a robustness check. We find that MNEs and NEs are undistinguishable in the short run, and we take
} 
state regulatory activity and union presence. Hiring and firing costs could be lower for MNEs because they can adjust employment by simply shifting employees from one subsidiary to another. Moreover, being MNEs relatively footloose and having a higher bargaining power (associated with the threat of shifting production to alternative locations), they may face fewer constraints than NEs with respect to government, political parties or unions. This would translate in general into lower procedural costs. The possibility of shifting employment across different locations in response to wage changes and the greater ability to bypass country-level labour market regulations may create an asymmetry in the behaviour of MNEs versus NEs not only in terms of the speed of employment adjustment, but also with respect to the extent of the desired adjustment. Thus, we expect that the same reasons that can explain lower adjustment costs of employment in MNEs would lead to higher wage elasticities in these firms, keeping equal the skill composition of employment.

To find some empirical support to these arguments we have correlated the ratio of the long-run wage elasticities in MNEs and NEs to a set of alternative country-level proxies of labour market conditions. Hiring costs are proxied by the educational attainment in the population (source Barro and Lee (1993)), on the expectation that the higher the proportion of educated labour force, the lesser are the costs of recruiting a skilled labour force and the lower are hiring costs. The most used measures for labour market rigidities are the employment protection indicators obtained from OECD. The different aspects of labour market regulation are summarised in an "overall indicator of the strictness of employment protection legislation", available for the period "late 90 's" ${ }^{17}$ It is not immediate to think of proxies for procedural inconvenience. We have considered the "overall indicator of product market regulation" (from Nicoletti, Scarpetta and Boylaud (2000)) and measures of union presence (from Checchi and Lucifora (2002)). ${ }^{18}$

Cross-country correlations between the ratio of long-run wage elasticities for NEs and MNEs and labour market indicators are reported in Table 4. Figure 1 reports plots of this ratio on selected labour market indicators. From the correlation of the ratio of wage elasticities with the share of population with college degree it emerges that the relative long-run wage elasticity in MNEs is positively affected by the availability of skilled labour. This evidence gives indirect support to the view that the structure of employment is more skill-intensive in MNEs. As hiring and firing skilled personnel is less costly when skilled labour is relatively abundant, skill intensive firms like MNEs tend to have a

this as reinforcing the result that the main difference is not in the short run adjustment (either wage or output elasticities), but in their speeds of adjustment.

${ }^{17}$ With respect to regular employment, OECD introduce the variable "overall strictness of protection against dismissal for regular employment", obtained as weighed average of "regular procedural inconvenience", "notice and severance pay for no-fault individual dismissals" and "difficulty of dismissal". We also tested "overall strictness of regulation for temporary work" (weighed average of "fixed-term contracts" and "temporary work agency") and "overall strictness of collective dismissal". The overall indicator of the strictness of employment protection legislation is a weighed average of these three indicators. All these scores range from 0 to 6 , with higher values representing stricter regulation.

18 The indicator of product market regulation summarises information on "State control", "Barriers to entrepreneurship",

"Barriers to trade and investment", "Economic regulation" and "Administrative regulation"; data are referred to 1998. 
relatively higher wage elasticity (see also the first quadrant of Figure 1). With respect to firing costs, correlation analysis shows that the relative wage elasticity of MNEs tends to rise with measures of rigidity of employment protection. This is easily understood by looking at the second quadrant of Figure 1: in countries characterised by stricter employment protection (e.g., Italy and France) the relative wage elasticity in MNEs is quite high (but still less than one), while in countries with more flexible labour markets (e.g., the UK) the wage elasticity in MNEs is considerably smaller than that in NEs. This confirms that MNEs are somehow in a better position to bypass country-specific regulations concerning employment protection. Similar arguments apply to product market regulation, which is also positively associated with relative wage elasticity (third quadrant of Figure 1). We also record a positive correlation between relative wage elasticity and union density, suggesting that MNEs are somehow able to counteract union power in countries where union are relevant (as measured by total union membership - see fourth quadrant of Figure 1).

Table 4 - Cross- country correlation indices between relative wage elasticities and proxies for labour market institutions - 11 countries - 1994-2000

\begin{tabular}{l|c} 
& $\begin{array}{c}\text { Ratio of long-run } \\
\text { wage elasticity } \\
\text { (MNE/NE) }\end{array}$ \\
\hline Population share with college degree & 0.3574 \\
\hline OECD overall rigidity indicator & 0.3263 \\
\hline OECD strictness of protection for regular employment & 0.4090 \\
\hline $\begin{array}{l}\text { OECD strictness of protection for temporary } \\
\text { employment }\end{array}$ & 0.2149 \\
\hline OECD overall product market regulation & 0.3914 \\
\hline Wage bargaining centralisation & 0.1324 \\
\hline Union net density & 0.4508 \\
\hline \multicolumn{1}{c|}{ Definition (see equation (3)) } & $\frac{\gamma_{4} /\left(1-\gamma_{1}\right)}{\left(\gamma_{4}+\gamma_{9}\right) /\left(1-\gamma_{1}-\gamma_{6}\right)}$
\end{tabular}

Note: Wage elasticities are considered in absolute terms Source: calculations on coefficients reported in Table 3

Overall, we can summarise our results as follows. MNEs are characterised by lower wage elasticity in the long run, irrespective of the country considered. While the wage elasticity in MNEs does not show much variation across countries, that in NEs seems more affected by country-level characteristics. Cross-country correlation analysis shows that the relative long-run wage elasticities in MNEs tend to rise with measures of skill availability, employment protection, product market regulation and union presence. This indicates that country-specific labour market regulations that tend to limit the capacity of firms to adjust employment (thus reducing labour demand wage elasticties) have a relatively smaller impact on MNEs. This evidence is consistent with the view that multinational firms, being relatively footloose and having greater bargaining power vis-à-vis host-countries' authorities and 
labour representatives, are in a better to position to bypass regulations affecting employment adjustment than purely national firms.

\section{Conclusions}

It is often argued that MNEs face lower costs than NEs in hiring and firing labour. As a consequence, they are expected to respond to shocks in technology, output and factor prices by adjusting their labour demand faster and to a greater extent than NEs. This paper examines if this is the case, by estimating dynamic labour demands for the two types of firms in elevan European countries.

In line with general beliefs, we find that MNEs adjust labour demands faster than NEs in all the sample countries. Within a year they achieve their optimal labour demand, whereas national firms take longer. In contrast, the extent of the adjustment is more limited: MNEs have generally smaller (in absolute terms) factor price and output long-run elasticities than NEs. We attribute the lower elasticities of MNEs to the higher skill intensity of their work force, although this cannot be directly measured in our database. Indirect evidence of this effect can nevertheless be derived from educational attainments in the total population and from average labour costs. Conditional on lower elasticity, MNEs enjoy a greater flexibility in employment adjustment with respect to NEs when labour and product markets are strictly regulated and/or unions are more powerful.

Our results address some of the worries emerging in the debate on the role of MNEs. Although MNEs create and destroy jobs faster than NEs, they are able to adjust more smoothly to shocks affecting their labour demands. For any given wage increase, for example, in the longer run MNEs reduce total employment less than national firms. In a sense, average jobs in MNEs are "safer" than in NEs. Also, we find that labour market regulations are quite irrelevant to the labour market behaviour of MNEs. These firms appear to be able to reach their optimal labour demand at fast speed independently of the labour market regime, and their long-run wage elasticity shows little variation across countries. Thus, concerns that labour market regulation may scare away foreign direct investments seem ill placed. 


\section{References}

Aitken J.D., A. Harrison, R. Lipsey, (1996), Wages and foreign ownership: A comparative study of Mexico, Venezuela, and the United States, Journal of International Economics, 40, 345-372.

Arellano,M., and S. Bond, (1991), Some tests of specification for panel data: Monte Carlo evidence and an application to employment equations, Review of Economic Studies, 58, 277-297.

Barro, R., and J.W.Lee. 1993. International comparisons of educational attainment. Journal of Monetary Economics 32 (3): 363-94.

Benfratello, L., and A. Sembenelli, (2002), Foreign ownership and productivity: Is the direction of causality so obvious?, paper presented at the CEPR/LdA Workshop on "Labour market effects of European foreign investment", Turin, May 2002.

Blonigen, B. and M. J. Slaughter, (2001), US skill upgrading and inward foreign direct investment, Review of Economics and Statistics, 83, 362-376.

Brakonier, H, and K. Ekholm (2000), Swedish multinationals and competition from high and low-wage locations, Review of International Economics, 8, 448-461.

Brainard, S., and A. Riker, (1997a), Are US multinationals exporting US jobs?, NBER Working Paper No. 5958.

Brainard, S., and D. Riker, (1997b), 'US multinationals and competition from low wage countries', NBER Working Paper No. 5959.

Bruno, G., Falzoni, A., M., and R. Helg, (2001), Measuring the effect of globalization on labor demand elasticity: An empirical application to OECD countries, mimeo, Università Bocconi.

Budd, J. W., J. Konings, and M. J. Slaughter, (2002), International rent sharing in multinational firms, NBER Working Paper No. 8809.

Checchi, D., and C. Lucifora, (2002), Union density - The economic roles of unions and institutions, forthcoming in Economic Policy 2002 (October).

Davies, S., and B. Lyons, (1991), Characterising the relative performance: The productivity advantage of foreign owned firms in the UK, Oxford Economic Papers , 43, 584-595.

Doms, M.E., and J.B. Jensen, (1998), Comparing wages, skills, and productivity between domestic and foreign owned manufacturing establishments in the United States”, in Baldwin, R., Lipsey, R. and Richardson, J. (eds.), Geography and Ownership as Bases for Economic Accounting, University of Chicago Press, Chicago.

Ehremberg, R., G., (1994), Labor Markets and Integrating National Economies, The Brookings Institution, Washington D.C. 
Fabbri, F., J. E: Haskel, and M. J. Slaughter, (2002), Globalisation and labour demand elasticities in Britain, paper presented at the "Adjusting to Globalisation" conference, University of Nottingham, June $28^{\text {th }}$ and $29^{\text {th }} 2002$.

Faini, R., A.M. Falzoni, M. Galeotti, R. Helg, and A. Turrini, (1999), Importing jobs and exporting firms? On the wage and employment implications of Italian trade and foreign direct investment flows, Giornale degli Economisti e Annali di Economia, 58, 95-135.

Fajnzylber, P., and W. F. Maloney, (2000), Labor demand and trade reform in Latin America, World Bank Discussion Paper No. 2491.

Feliciano Z., R.E. Lipsey, (1999), Foreign ownership and wages in the United States, 1987-1992, NBER Working Paper No. W6923.

Feenstra, R., and G. Hanson, (1997), Foreign direct investment and relative wages: Evidence fro Mexico's maquilladoras, Journal of International Economics, 42, 371-393.

Girma, S., D. Greenaway, and K. Wakelin, (2001), Who benefits from foreign direct investment in the UK?, Scottish Journal of Political Economy, 48, 119-133.

Girma, S., D. Greenaway, and K. Wakelin, (2002), Wages, productivity and foreign ownership in UK manufacturing, Scottish Journal of Political Economy, forthcoming.

Globerman, S., J. Ries, and I. Vertinsky, (1994), The economic performance of foreign affiliates in Canada, Canadian Journal of Economics, 27, 143-156.

Gorg, H., and E. Strobl, (2002), Footloose multinationals?, Manchester School, forthcoming.

Griffith, R., (1999), Using the ARD establishment level data to look at foreign ownership and productivity in the UK, Economic Journal, 109, 416-442.

Griliches, Z., and J. A: Hausman, (1986), Errors in variables in panels data, Journal of Econometrics, 31, 93-118.

Hamermesh, D. S., (1993), Labor Demand, Princeton University Press, Princeton.

Hatzius, J., (1998), Domestic jobs and foreign wages, Scandinavian Journal of Economics, 100, 733746.

Katz, H. C., (1993), The decentralization of collective bargaining: a literature review and comparative analysis, Industrial and Labor Relations Review, 47, 3-22.

Krishna, P., D. Mitra, and S. Chinoy, (2001), Trade liberalization and labour demand elasticities: evidence from Turkey, Journal of International Economics, 55, 391-409.

Lipsey, R., (1994), Foreign-owned firms and U.S. wages, NBER Working Paper No. 4927.

Lipsey, R., (2000), Interpreting developed countries’ foreign direct investment, NBER Working Paper No. 7810.

Markusen, (2002), Multinational Firms and the Theory of International Trade, Cambridge MA, The Mit Press. 
Mezzetti, C., and E. Dinopoulos, (1991), Domestic unionisation and import competition, Journal of International Economics, 31, 79-100.

Nicoletti, G., S. Scarpetta and O. Boylaud, (2000), Summary indicators of product market regulation with an extension to employment protection legislation, OECD working paper No. 226/2000.

OECD, (1999), Employment Outlook (Chapter .2 - Employment protection and labour market performance), OECD, Paris

Rodrik, D., (1997), Has Globalization Gone Too Far?, Washington, Institute for International Economics.

Shatz, and A.J. Venables, (2001), The geography of international investment, forthcoming in G. L. Clark, M. Feldman and M.S. Gertler (eds.), The Oxford Handbook of Economic Geography, Oxford University Press, Oxford.

Slaughter, M. J., (2000), Production transfer within multinational enterprises and American wages, Journal of International Economics, 50, 449-472.

Slaughter, M. J., (2001), International trade and labor demand elasticities, Journal of International Economics, 54, 27-56.

UNCTAD, (1999, 2001), World Investment Report, United Nations, New York and Geneva.

Zhao L. (1998), The impact of foreign direct investment on wages and employment, Oxford Economic Papers, 50, 284-301. 
APPENDIX 1: Nationals vs. Multinationals: summary statistics for the firms in the sample ${ }^{a}(1998)$

\begin{tabular}{|c|c|c|c|c|}
\hline & & $\begin{array}{c}\text { Average } \\
\text { employment } \\
\text { per firm (units) }\end{array}$ & $\begin{array}{c}\text { Average output } \\
\text { per employee } \\
(000 \text { US } \$)^{\mathrm{b}}\end{array}$ & $\begin{array}{l}\text { Average labour cost } \\
\text { per employee } \\
(000 \text { US \$) }\end{array}$ \\
\hline Belgium & $\begin{array}{l}\text { NE } \\
M N E \\
\text { National average }^{c}\end{array}$ & $\begin{array}{c}214.58(310.02) \\
535.24(1083.47)\end{array}$ & $\begin{array}{c}274.92(262.56) \\
333.9(299.92) \\
189.18\end{array}$ & $\begin{array}{c}43.46(17.49) \\
54.97(15.04) \\
33.27\end{array}$ \\
\hline Denmark & $\begin{array}{l}\text { NE } \\
\text { MNE } \\
\text { National average } \\
\end{array}$ & $\begin{array}{l}323.38(446.86) \\
236.72(213.33)\end{array}$ & $\begin{array}{c}215.45(194.23) \\
216.82(124.07) \\
160.24\end{array}$ & $\begin{array}{c}44.49(9.43) \\
47.63(10.23) \\
40.69\end{array}$ \\
\hline Spain & $\begin{array}{l}\mathrm{NE} \\
\text { MNE } \\
\text { National average }\end{array}$ & $\begin{array}{l}274.48(872.54) \\
441.73(988.09)\end{array}$ & $\begin{array}{c}238.56(283.82) \\
307.12(232.38) \\
\text { n.a. }\end{array}$ & $\begin{array}{c}30.21(10.81) \\
41.06(14.03) \\
\text { n.a. }\end{array}$ \\
\hline Finland & $\begin{array}{l}\text { NE } \\
\text { MNE } \\
\text { National average } \\
\end{array}$ & $\begin{array}{c}323.4(348.34) \\
230.34(223.09)\end{array}$ & $\begin{array}{c}245.19(158.49) \\
246.47(140.73) \\
156.71 \\
\end{array}$ & $\begin{array}{c}42.52(9.42) \\
42.61(8.76) \\
27.05 \\
\end{array}$ \\
\hline France & $\begin{array}{l}\mathrm{NE} \\
\text { MNE } \\
\text { National average } \\
\end{array}$ & $\begin{array}{c}496.51(1896.10) \\
354.92(519.63)\end{array}$ & $\begin{array}{c}243.44(299.85) \\
271.03(244.04) \\
155.86\end{array}$ & $\begin{array}{c}41.91(14.57) \\
46.23(14.21) \\
30.16\end{array}$ \\
\hline Germany & $\begin{array}{l}\text { NE } \\
M N E \\
\text { National average } \\
\end{array}$ & $\begin{array}{l}1731.55(4075.65) \\
1626.71(2012.65)\end{array}$ & $\begin{array}{c}309.07(201.43) \\
453.07(773.92) \\
119.39\end{array}$ & $\begin{array}{c}60.61(20.04) \\
63.33(20.63) \\
30.94\end{array}$ \\
\hline Italy & $\begin{array}{l}\text { NE } \\
M N E \\
\text { National average } \\
\end{array}$ & $\begin{array}{l}213.82(633.30) \\
419.75(722.81)\end{array}$ & $\begin{array}{c}223.67(143.20) \\
385.04(454.61) \\
109.82 \\
\end{array}$ & $\begin{array}{c}34.82(9.94) \\
45.27(13.54) \\
19.19 \\
\end{array}$ \\
\hline Netherlands & $\begin{array}{l}\text { NE } \\
M N E \\
\text { National average } \\
\end{array}$ & $\begin{array}{l}2162.71(5114.76) \\
1046.71(2969.12)\end{array}$ & $\begin{array}{c}339.87(321.39) \\
381.24(297.20) \\
145.30 \\
\end{array}$ & $\begin{array}{c}47.71(12.42) \\
49.77(10.77) \\
25.72 \\
\end{array}$ \\
\hline Norway & $\begin{array}{l}\mathrm{NE} \\
M N E \\
\text { National average }\end{array}$ & $\begin{array}{l}133.36(231.28) \\
189.01(217.94)\end{array}$ & $\begin{array}{c}157.37(162.83) \\
228.79(159.35) \\
\text { n.a. }\end{array}$ & $\begin{array}{c}34.92(12.97) \\
50.26(13.79) \\
\text { n.a. }\end{array}$ \\
\hline Sweden & $\begin{array}{l}\mathrm{NE} \\
M N E \\
\text { National average }\end{array}$ & $\begin{array}{l}285.98(803.16) \\
408.17(671.10)\end{array}$ & $\begin{array}{c}195.94(144.05) \\
239.16(187.39) \\
200.52\end{array}$ & $\begin{array}{c}29.64(5.57) \\
32.59(5.76) \\
40.26\end{array}$ \\
\hline $\begin{array}{l}\text { United } \\
\text { Kingdom }\end{array}$ & $\begin{array}{l}\text { NE } \\
\text { MNE } \\
\text { National average }\end{array}$ & $\begin{array}{l}529.93(2305.81) \\
495.91(1244.04)\end{array}$ & $\begin{array}{c}169.87(213.94) \\
232.72(397.37) \\
147.04\end{array}$ & $\begin{array}{c}31.70(10.43) \\
35.44(12.92) \\
38.02\end{array}$ \\
\hline
\end{tabular}

aStandard deviations into brackets;

b Output is proxied by operating revenue (000 US\$);

'Source: OECD STAN Database, OECD, Paris, 2001

APPENDIX 2: Description of the variables used in the estimations

\begin{tabular}{c|c} 
Variable & Description \\
\hline$l_{i t}$ & Number of employees $^{\mathrm{a}}$ \\
$w_{i t}$ & Real labour costs ${ }^{\mathrm{a}, \mathrm{b}}$ \\
$y_{i t}$ & Real operating revenue ${ }^{\mathrm{a}, \mathrm{b}}$ \\
$r_{i t}$ & Real rental cost of capital \\
& $r_{t}=\log \left(\frac{1+i_{t}}{P_{i t} / P_{i t-1}}-1\right)$
\end{tabular}

where $i_{t}=$ country-level nominal interest rate and $P_{i t}=$ industry-

level price index ${ }^{b}$

a Source: Amadeus Database, 2001.

b Deflators are industry-level (SIC 2 digits) producer price indexes. Source: OECD, STAN database, OECD, Paris, 2001.

c Source for country-level nominal interest rates: IMF, International Financial Statistics, IMF, Washington DC, 2000. 

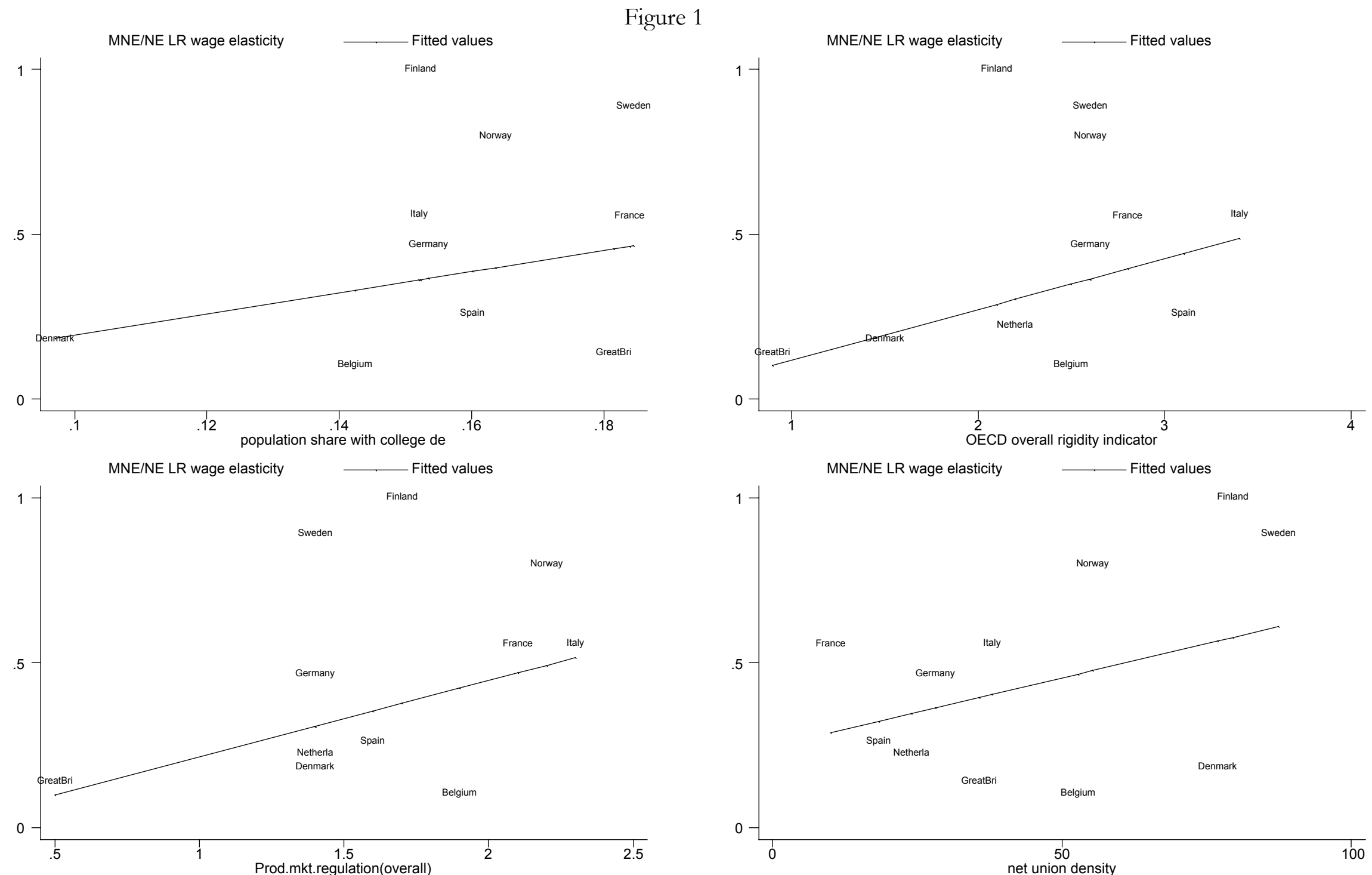

Relative long run wage elasticities and labour market variables 